Nig. J. Biotech. Vol. 37(2): 103-112 (Dec. 2020)

ISSN: 01891731

Available online at

http://www.ajol.info/index.php/njb/index

and www.biotechsocietynigeria.org

DOI: https://dx.doi.org/10.4314/njb.v37i2.10

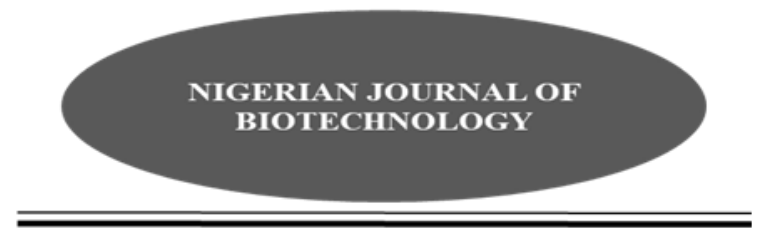

\title{
Isolation and Molecular Identification of some Fungi Associated with Jatropha curcas (L.)
}

\author{
1,2* Iyanyi, N. G. and 1,2Ataga, A. E. \\ ${ }^{1}$ Department of Plant Science and Biotechnology, University of Port Harcourt, Port Harcourt, Nigeria. \\ ${ }^{2}$ Regional Center for Biotechnology and Bio-resources Research, University of Port Harcourt, Port Harcourt, \\ Nigeria.
}

\begin{abstract}
Jatropha curcas is a plant of great economic importance that experiences high incidence of fungal attack. Misidentification of the fungal species is bound to occur with the use of traditional cultural methods where organisms are identified morphologically and/or microscopically. This study was carried out to isolate and identify the fungi associated with Jatropha curcas (L.) using both traditional/ cultural techniques and molecular methods. The fungi were isolated from diseased leaves and stems of $J$. curcas using both Standard Blotter and Potato Dextrose Agar (PDA) methods. DNA was extracted from the fungal isolates using Zymo Fungal/Bacteria DNA MiniPrep Kit. Amplification of the Internal Transcribed Spacer (ITS) regions of the fungal isolates was carried out using fungi universal primer pairs for ITS4 and ITS5. The amplicons were sequenced and the isolates were identified as Penicillium brevicompactum, Aspergillus sp., Botryosphaeria rhodina, Aspergillus nomius, Aspergillus tamarii, Rhizopus oryzae, Penicillium citrinum and Fusarium solani. Phylogenetic analysis was carried out to know the relationship between the isolates and other closely-related species in GenBank. Jatropha curcas is colonized by many fungal species some of which may be pathogenic to the plant, and molecular techniques pose the best alternative for accurate identification of these organisms.
\end{abstract}

Keywords: Jatrophacurcas, fungi, polymerase chain reaction, phylogeny, sequencing.

Corresponding author's e-mail: nkechi.iyanyi@gmail.com,Tel: +2347037829855

\section{Introduction}

Jatropha curcas (Linn.), commonly called "Jatropha" or "physic nut", is a droughtresistant multipurpose shrub that originated from Mexico and Central America (SalvadorFigueroa et al., 2015). Today, the plant is cultivated world-wide as a hedge crop and for traditional purposes in both tropical and subtropical regions (Agbogidiet al., 2013).

Jatropha is a plant with many economic values. The unique oil extracted from the seeds can be used as a feed stock for biodiesel (Maghulyet al., 2013). The seed cake serves as inorganic manure and when derived from a non-toxic variety of Jatropha curcas, it may be used as animal feed. The leaves, bark, shoot latex, roots and seed oil are used for medicine and veterinary purposes. In the rural areas in Nigeria such as Aluu, Omuigwe, in Ikwere LGA; and Rumuji, Oduoha in Emohua LGA both in Rivers State, Jatropha leaf is believed to aid in fermentation of cassava and is used for this purpose. After peeling and soaking the cassava, Jatropha leaves are placed on top of the cassava and this reduces the number of days required for the cassava to ferment. The fruit exocarp (coat), seed shell and the press cake of the seed are rich in 
nitrogen, phosphorous and potassium and can be used as an inorganic fertilizer to improve plants growth (Islam et al., 2011).

Plant diseases can be as a result of nutrient deficiency or invasion by pathogenic microorganisms. Most diseases of plants are caused by fungal organisms. Jatropha curcas was previously believed to have a strong resistance against diseases because of the presence of many disease-fighting compounds such as palmitic, palmitoleic, stearic and linoleic acid methyl esters present in the plant (Rahmanet al., 2014). Many studies have shown that $J$. curcas is susceptible to fungal attacks (Jayaramanet al., 2011; Nwaukwu et al., 2014; Lateefet al. 2019).

Isolation and/or characterization of microorganisms can be carried out using traditional cultural techniques or molecular methods such as culture-dependent [Polymerase Chain reaction (PCR)] and culture-independent (metagenomics) methods. Traditional cultural techniques are based on macroscopic and microscopic examination of the isolates. Standard approaches for identification of microorganisms such as the use of culture media and biochemical tests are known to be very time-consuming and laborious (FrancoDuarte et al., 2019). One of the efficient strategies used to reduce the time required for the identification of microorganisms is the use of molecular biology techniques which may be used alongside several molecular fingerprinting techniques (Castro-Escarpulliet al., 2016). Fast and accurate detection and identification of microorganisms is very critical in today's sphere of life science. Molecular techniques can be quick and cost effective in classifying fungal and bacterial species , especially if the microorganisms under study are better understood (FrancoDuarte et al., 2019). This study was carried out to isolate and identify fungal organisms associated with Jatropha curcas using molecular techniques.

\section{Materials and Methods}

\section{Study Area and Sample Collection}

The study was carried out at the Regional Centre for Biotechnology and Bio-resources Research, University of Port Harcourt, Rivers State, Nigeria. Sequencing was carried out at the International Institute of Tropical Agriculture (IITA), Ibadan.

Diseased leaves and stems of Jatropha curcas showing symptoms such as chlorosis, leaf spots, necrosis, leaf dropping, stunted growth, wilting, leaf crumple, blight etc were collected from the three senatorial zones in Rivers State : Obio-Apor, Ikwere, Port Harcourt and Emuoha Local Government Areas (LGAs) for River East; Ahoada-East, Ahoada-West, Ogba/Egbema/Ndonni and Degema LGAs for Rivers West; and Tai, Eleme and Oyigbo LGAs for Rivers South-east senatorial zones.

\section{Isolation of Fungi from Jatropha curcas}

The isolation of fungi associated with Jatropha curcas was carried out using the Standard Blotter recommended by the International Rules for Seed Testing Association (ISTA, 2016) and Potato Dextrose Agar (PDA) methods. Three layers of Whatman's filter papers were soaked in sterile distilled water and placed in sterilized glass Petri-dishes of $9 \mathrm{~cm}$ in diameter. The Jatropha leaves and stems were surface sterilized by soaking in $70 \%$ ethanol for 5 minutes, rinsed with sterile distilled water for three consecutive times before plating the plant tissues on the Petridishes and then incubated for 7 days at room temperature $\left(28 \pm 2^{\circ} \mathrm{C}\right)$. The frequency of occurrence of each fungus was determined. After the incubation period, the observed fungal colonies on the plates were transferred into sterilized Potato Dextrose Agar (PDA) medium in Petri dishes to obtain pure cultures. Petri dishes containing fungal cultures were incubated for 7 days at room temperature $\left(28 \pm 2^{\circ} \mathrm{C}\right)$. Pure cultures of the isolates were preserved in a refrigerator at $4^{\circ} \mathrm{C}$ until when needed.

\section{Fungal DNA Extraction, DNA Quantification and Quality Check}

Genomic DNA of fungal isolates was extracted following the protocol of Quick-DNA Fungal/Bacterial MiniPrep Kit (Zymo Research Group, California, USA) as described by the manufacturer, with slight modifications as obtainable at the Regional Centre for Biotechnology and Bio-resources Research Laboratory, University of Port Harcourt, Rivers State, Nigeria. A sterilized surgical blade was used to scrape off the fungal mycelium. This 
was homogenized in a sterilized mortar using $750 \mu$ l of Bashing Bead Buffer and liquid nitrogen.

The concentration and purity of the DNA were determined using Nanodrop 2000c Spectrophotometer (Thermo Fisher Scientific Inc. Wilmington, Delaware, USA). DNA quality was determined by gel electrophoresis using $1 \%$ agarose gel.

\section{PCR Amplification and Sequencing}

Fungal universal primer pair ITS4, forward: (5'-TCCTCCGCTTATTGATATGS-3') and ITS5, reverse: (5'-GGAAGTAAAAGTCGTAACAAGG$\left.3^{\prime}\right)$, were used to amplify the ITS1-2 region of the isolates. The PCR cocktail consisted of $3 \mu \mathrm{L}$ of genomic DNA $(10 \mathrm{ng} / \mu \mathrm{L}), 0.1 \mu \mathrm{L}$ of Taq polymerase, $2.5 \mu \mathrm{L}$ of $10 \mathrm{X}$ PCR buffer, $1.0 \mu \mathrm{L}$ of DMSO, $1.0 \mu \mathrm{L}$ of $2.5 \mathrm{mM}$ DNTPs, $1.0 \mu \mathrm{L}$ of $25 \mathrm{mM} \mathrm{MgCl} 2$ (Promega), $1.0 \mu \mathrm{L}$ of each primer (concentration of $5 \mu \mathrm{M}$ ) and $13.4 \mu \mathrm{L}$ of Nuclease-free water, making a total volume of $25 \mu \mathrm{L}$. Amplifications were performed in a thermal cycler (GeneAmp $® 9700$ PCR System, Applied Biosystems, California, USA) using an initial denaturation step of $94^{\circ} \mathrm{C}$ for 5 minutes, followed by 36 cycles of denaturation at $94^{\circ} \mathrm{C}$ for 30 seconds, annealing at $54^{\circ} \mathrm{C}$ for 30 seconds and elongation at $72^{\circ} \mathrm{C}$ for 45 seconds with a final extension at $72^{\circ} \mathrm{C}$ for 7 minutes. The amplicons were stored at $10^{\circ} \mathrm{C}$. Amplified products were sequenced on $A B I$ 3500 Genetic Analyzer (Thermo Fisher Scientific, Massachusetts, U.S.A).

\section{Data Analysis and Phylogeny}

The generated raw sequences of the isolates were edited to remove PCR artifacts and sequencing noise using Molecular Evolutionary Genetics Analysis (MEGA) software, version 10.0.1 (MEGA X) (Kumar et al., 2018). A BLAST $n$ search was conducted using the edited sequences against the GenBank database at the National Centre for
Biotechnology Information (NCBI) database for identification of the isolates. A multiple sequence alignment of the sequences obtained from the search query of the isolates was carried out using Clustal W program and a neighbour-joining phylogenetic tree was constructed using maximum composite likelihood method. Other data obtained from the study were analyzed using One-way Analysis of Variance (ANOVA) $(P<0.05)$ with the aid of Statistical Package for Social Science (SPSS) software version 23.0

\section{Results}

Fungal Species Isolated from Jatropha curcas

Based on our morphological characterization on PDA plates (Figure 1 and Table 1), eight fungal species were isolated from the leaves and stems of Jatropha curcas. The frequency of occurrence and the morphological characteristics of the isolates are presented in Table 1.

For the organisms isolated from the leaves, sample 2 had the highest mean occurrence (42.00), followed by sample 8 (37.00), sample 7 (28.66), sample 3 (25.00), sample 5 (21.00), sample 6 (18.00), sample 4 (12.00) and sample 1 (10.33). For organisms isolated from the stem, sample 8 had the highest mean occurrence $(50.00)$ followed by sample 2 (41.00), sample 7 (31.00), sample 3 (26.66), sample 5 (21.33) and lastly sample 6 (18.00). Sample 1 and 4 were not found in the stems. More fungal isolates were obtained from the leaves than from the stems of the $J$. curcas trees sampled. Pure cultures of the fungal isolates are presented in Figure 1. The Zymo Fungal /Bacteria Miniprep kit effectively extracted the fungal DNA and yielded good quality DNA with $260 / 280 \mathrm{~nm}$ ratio between 1.78 and 2.13 .

Table1: Mean occurrence of fungal isolates from Jatrophacurcas leaves and stem.

\section{FungalJatrophacurcas}

\begin{tabular}{llrrr}
\hline Isolate ID & Morphological Characteristics & Leaves & Stem \\
\hline 1 & Dark green with white edges and powdery surface & $10.33^{\mathrm{a}}$ & $0.00^{\mathrm{b}}$ &
\end{tabular}

\begin{tabular}{llll}
\hline 2 & Green colony with a powdery surface & $42.00^{\mathrm{f}}$ & $41.00^{\mathrm{b}}$ \\
\hline
\end{tabular}


Iyanyi and Ataga ./ Nig. J. Biotech. Vol. 37 Num. 2: 103-112 (Dec 2020)

\begin{tabular}{llrr}
\hline 3 & Dark grey cottony colonies & $25.00^{\mathrm{c}}$ & $26.66^{\mathrm{a}}$ \\
4 & Velvety colonies, brownish green in colour & $12.00^{\mathrm{a}}$ & $0.00^{\mathrm{b}}$ \\
5 & Bronze to dark-brown velvety colonies with & $21.00^{\mathrm{b}}$ & $21.33^{\mathrm{b}}$ \\
& conspicuously roughened thick walls & \\
6 & Copious cottony colony with black globules & $18.00^{\mathrm{b}}$ & $18.00^{\mathrm{a}}$ \\
7 & Dark green granular colony with powdery surface & $28.66^{\mathrm{a}}$ & $31.00^{\mathrm{b}}$ \\
8 & Snow white colony that changes to pink as the & $37.00^{\mathrm{a}}$ & $50.00^{\mathrm{a}}$ \\
& culture becomes old & & \\
Total & & 24.25 & 23.62 \\
ANOVA) F-statistics & & \\
p-value 0.000 & & & \\
\hline
\end{tabular}

Each value is a mean of three test replicates at $95 \%$ confidence limit

Row mean \pm standard deviation with different alphabet is significant at $5 \%$.

The ANOVA result showed that for leaves and stem fungi isolates are significant at $p$-value $(0.000)<5 \%$ significant
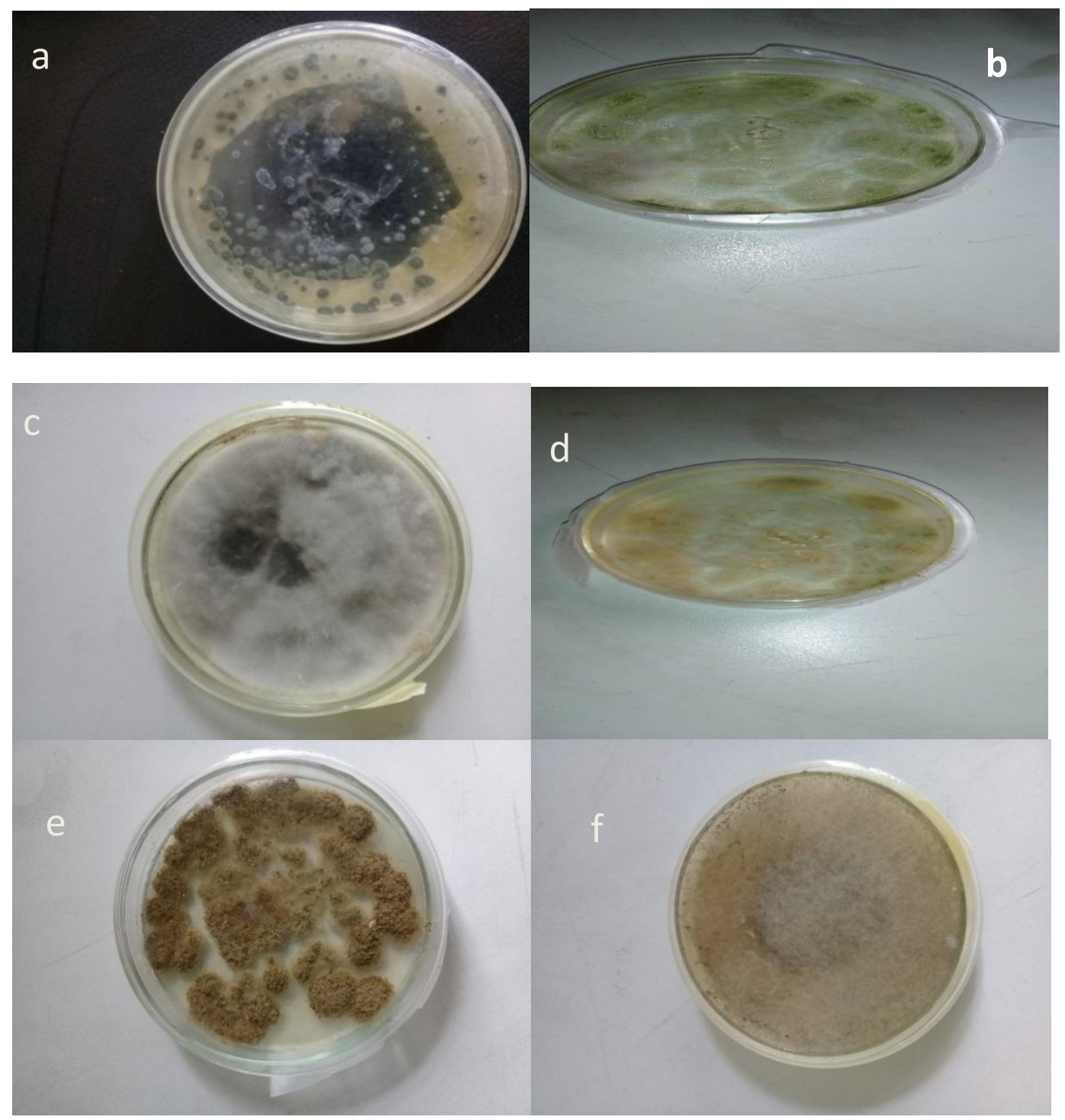


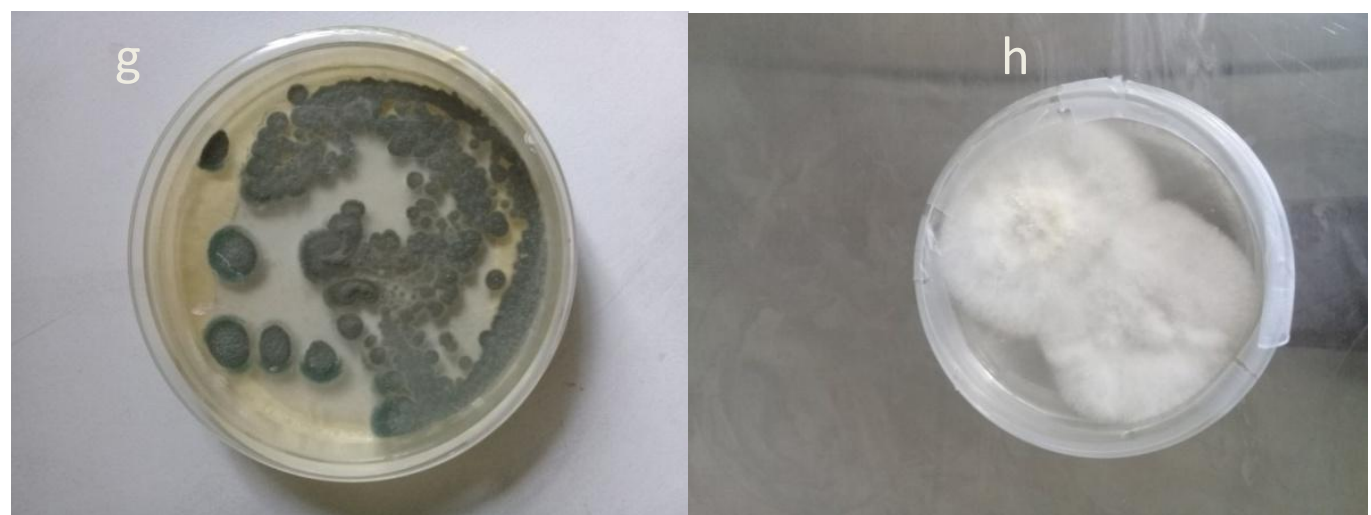

Figure 1: Pure cultures of the fungi isolated from Jatropha curcas leaves and stems, grown on Potato Dextrose Agar at $27 \pm 2^{\circ} \mathrm{C}$.

The alphabets ( $a$ to $h$ ) represent the fungal isolates ( 1 to 8 )

\section{Polymerase Chain Reaction (PCR)}

The quantity and quality of the extracted DNA were able to yield a good result with PCR. Gel bands of the amplicons from the PCR, as viewed under UV light, are shown Figure 2.

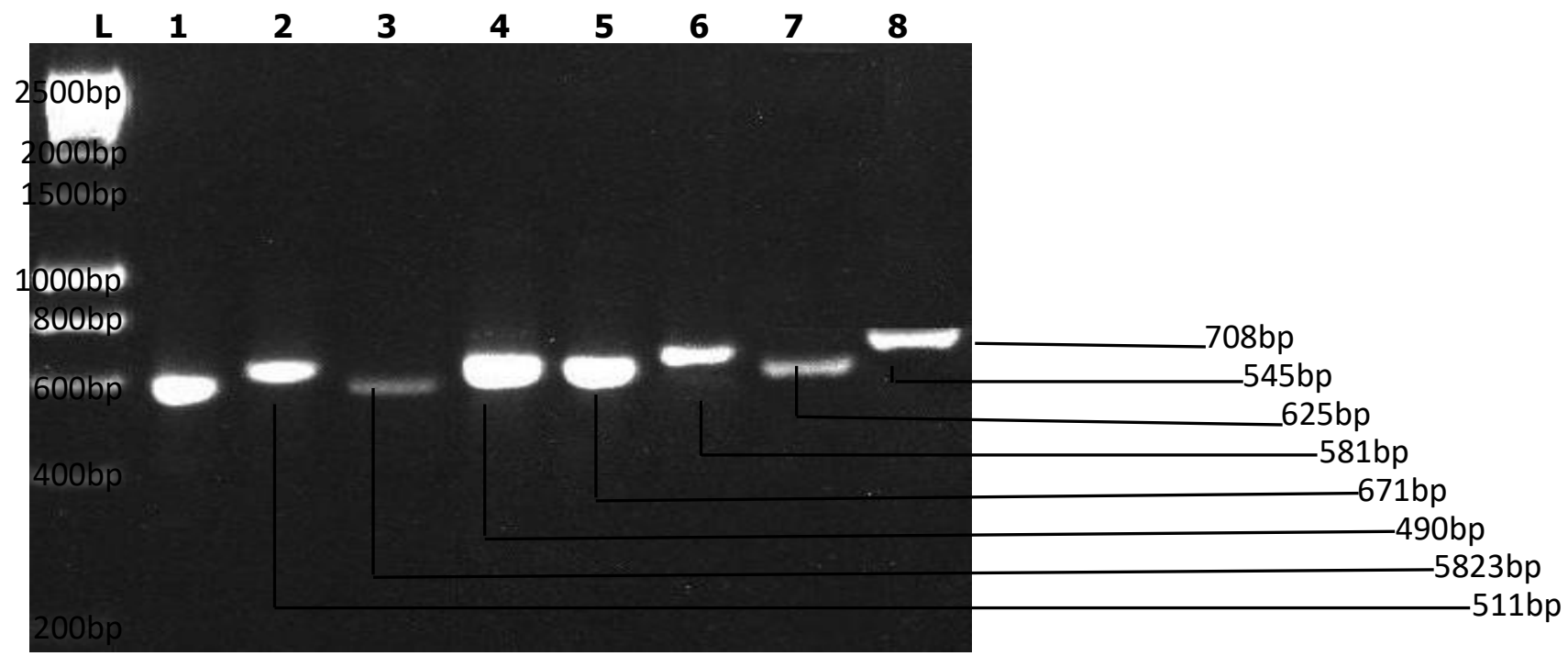

Figure 2: Gel electropherogram showing the results of PCR amplification generated from the ITS1-2 region of the fungal isolates.

$\mathrm{L}$ - 1kb DNA Ladder; the numbers (1 to 8 ) represent the fungal isolates

\section{Identification of Fungal Isolates}

The nucleotide lengths of each ITS sequence obtained from the fungal isolates of Jatropha curcas was determined to be $511,582,490$, $671,581,625,545$ and 708 base pairs for the fungal isolates 1 to 8 , respectively. The sequence alignments of all the samples were enough for identification of isolates with a high confidence limit.

A BLAST search using the sequences of the fungal ITS1-2 was conducted at the
NCBI database and the identity of the isolates was revealed to be Penicillium brevicompactumDierckx, Aspergillus sp. Micheli, Botryosphaeria rhodina (Berk and Curtis) Arx, Aspergillus nomius Kurtzman, B. W. Horn \& Hesseltine, Aspergillus tamarii Kita, Rhizopus oryzae Went and Prins. Geerl., Penicillium citrinum Thom, C. and Fusarium solani (Mart.) Sacc., for the fungal isolates 1 to 8 , respectively. Table 2 shows the taxonomic affinities of the isolates with searches on the nucleotides database of 
GenBank using Basic Local Alignment Search Tool (BLAST).

Table 2: Taxonomic affinities of sequence types inferred from BLAST searches of ITS sequences obtained from fungal isolates of Jatropha curcas.

\begin{tabular}{llc}
\hline Fungal Isolate ID & $\begin{array}{l}\text { Taxonomic affinity } \\
\text { (Gene bank no.) }\end{array}$ & Similarity (\%) \\
\hline 1 & Penicillium brevicompactum (MH634497.1) & 89 \\
2 & Aspergillus sp. (HM560042.1) & 87 \\
3 & Botryosphaeria rhodina (HM156070.1) & 91 \\
4 & Aspergillus nomius (MG575481.1) & 85 \\
5 & Aspergillus tamarii (JN419193.1) & 95 \\
6 & Rhizopus oryzae (MG554240.1) & 95 \\
7 & Penicillium citrinum (MG554246.1) & 98 \\
8 & Fusarium solani (KJ620369.1) & 98 \\
\hline
\end{tabular}

The DNA sequences obtained were submitted to the GenBank and each sequence was assigned an accession number (in parenthesis) as follows:

Penicillium brevicompactum(MK447615) strain RCBBR_AEANK1

Aspergillus sp. (MK881171) strain RCBBR_AEANK2

Botryosphaeria rhodina (MK447616) strain RCBBR_AEANK3

Aspergillus nomius (MK989664) strain RCBBR_AEANK4

Aspergillus tamarii (MK447617) strain RCBBR_AEANK5

Rhizopus oryzae (MK447618) strain RCBBR_AEANK6

Penicillium citrinum (MK447619) strain RCBBR_AEANK7

Fusarium solani (MK447620) strain RCBBR_AEANK8

Phylogenetic Analysis

Phylogenetic tree was constructed to establish the relationship between the fungal species isolated from Jatropha curcas and other known species on GenBank. The sequence analysis showed genetic diversity among the isolates with three other isolates belonging to the genus Aspergillus. Aspergillus caelatus, Aspergillus toxicarius, Penicillium sp., Lasiodiplodia theobromae, Rhizopus delemar and Fusarium oxyspor um were most closely related to the fungal isolates from this study (Figure 3 ). The tree enriches our understanding of how the fungal species evolved; which organisms evolved before the other. The greater the length of the vertical lines on the tree, the more the difference between the organisms. 


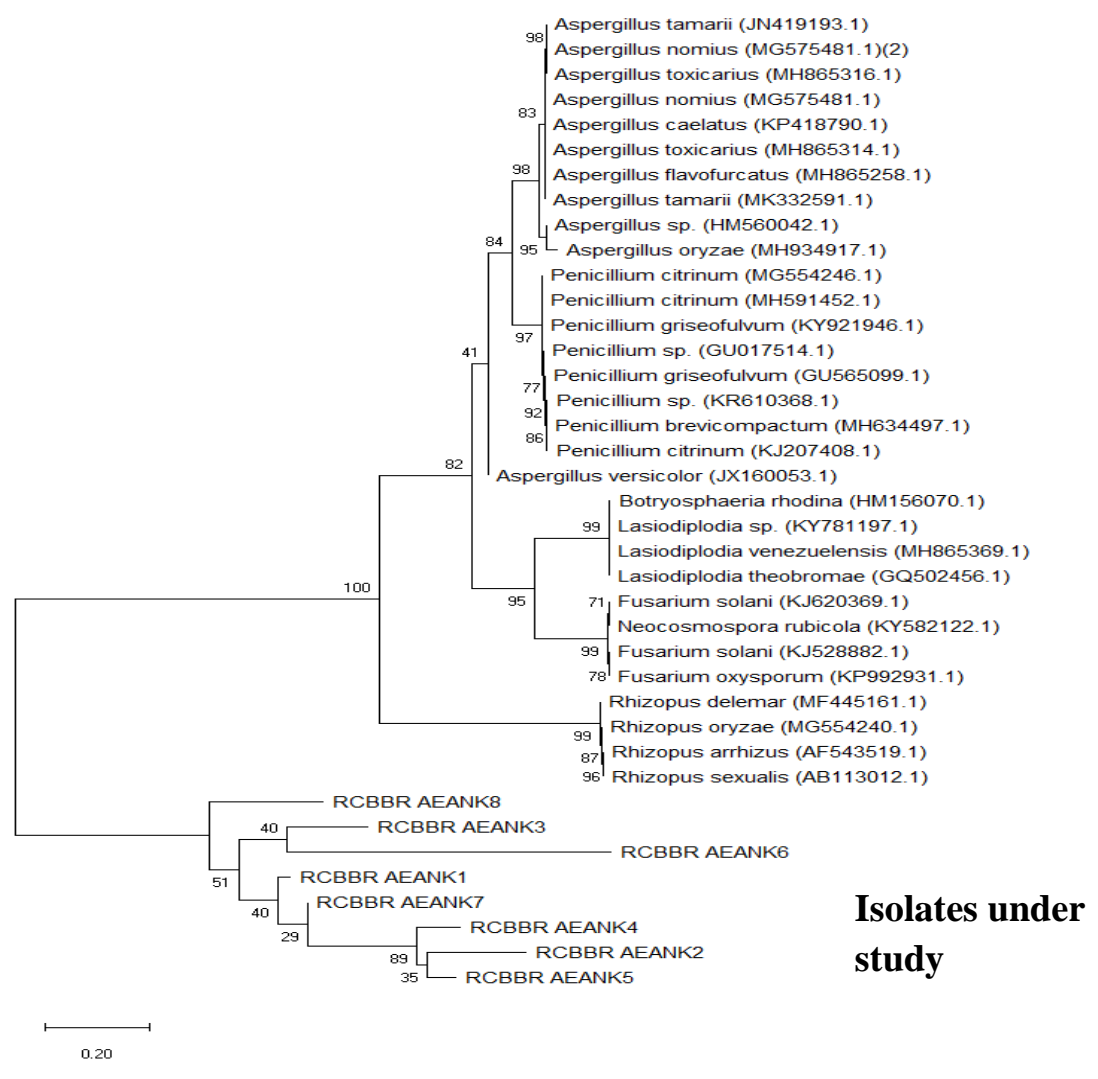

Figure 3: Phylogenetic tree showing the relationship between fungal species isolated from Jatropha curcas and other closely related species on GenBank.

\section{Discussion}

Eight fungal organisms, Penicillium brevicompactum, Aspergillus sp., Botryosphaeria rhodina, Aspergillus nomius, Aspergillus tamarii, Rhizopus oryzae, Penicillium citrinum and Fusarium solani were isolated from Jatropha curcas using the traditional cultural method and identified using molecular techniques.

Fungal organisms associated with Jatropha curcas have been reported by some authors. Nwaukwu et al. (2014) reported the occurrence of Alternaria alternata, Botryodi plodia theobromae , Cercospora beticola, and Macrophomina phaseolina on diseased leaves of Jatropha curcas. Jayaramanet al. (2011) isolated Aspergillus glaucus, A. flavus, A. nigerand Penicillium citrinum from seeds of Jatropha curcas. Woranget al. (2008) reported the occurrence of Aspergillus ochraceus, $A$. penicillioides, A. tamarii, Fusarium moniliforme, and Penicillium citrinum on
Jatropha curcas seeds. All these fungi were isolated using Standard Blotter and Potato Dextrose Agar methods and identified by microscopy.

Lateef et al., (2019) isolated Curvularia geniculata and Phyllosticta capitalensis from Jatropha curcas leaves using morphological and molecular methods. These organisms are endophytes and establish symbiotic- topathogenic relationships with plants. These fungi can assume a pathogenic condition when the host plant is under stress. Santos et al., (2013) isolated Colletotrichum capsici and Colletotrichum gloeosporioides from seeds of Jatropha curcas through morphological, cultural, and molecular analyses. Leaves and fruits of the physic nut are susceptible to anthracnose caused by species of Colletotrichum capsici and Colletotrichum gloeosporioides.

Most of the fungal isolates obtained from this study are plant pathogens. Leaf dropping and 
leaf crumple which were among the symptoms observed on the sampled J. curcas leaves are symptoms associated with fungal diseases of plants. Destruction of succulent plant tissues (blight) such as leaves and shoots were also obtained from the J. curcas plants sampled. Leaf spots which are localized lesions produced on plant leaves due to fungal invasion was also observed on the sampled leaves. Fusarium species are known to cause wilting of plants; some of the sampled $J$. curcas plants showed this symptom. The genera Aspergillus and Penicillium produce several mycotoxins which cause diseases in plants and health complications in man and animals. Aspergillus nomius and Aspergillus tamarii are usually misinterpreted as Aspergillus flavus based on phenotype; but using molecular methods such as ITS, Calmodulin Gene and $\beta$-Tubulin sequencing, these organisms are identified as distinct species (Tam et al., 2014).

Aspergillus tamarii is an endophytic fungus that could be a potential source of antibacterial agents. Ogboleet al., (2017) reported the antibacterial activity of Aspergillus tamarii against Salmonella typhi, Staphylococcus aureus, Bacillus subtilis and Escherichia coli. A. tamarii has also been reported to produce the enzyme, tannase which is used in the food industry (Costa et al., 2008). Aspergillus tamarii has been found to be pathogenic to man. The production of aflatoxin $\mathrm{B} 1$ and $\mathrm{G} 1$ by $A$. nomius strain ASR3 has also been reported by Da SilvaJunior et al. (2017).

Penicillium citrinum is known to produce a mycotoxin called citrinin. $P$. citrinum has been recorded as one of the seed-borne pathogenic fungi in common bean (Phaseolus vulgaris) (Marcenaro and Valkonen, 2016). P. citrinum has also been connected with the promotion of plant growth and mitigation of the adverse effects of stem rot (Muhammad et al., 2015). Penicillium brevicompactum and. $P$. solitum were reported as pathogenic organisms on pear (Louw and Korsten, 2014). Wang et al., (2011) reported Botryosphaeria rhodina as one of the pathogens responsible for gummosis on Peach (Prunuspersica) trees in China. Symptoms include dark lesions on twigs and branches and in some trees, gum exudation occurred from diseased parts.
Rhizopus oryzae has been reported to be responsible for soft rot on banana, apple, avocado and guava (Jin-Hyeuket al., 2011; Jin-Hyeuket al., 2012; Kurniawati and Sardjono, 2014). $R$. oryzae has also been reported to produce lactic acid which is widely used in food and food-related products (Kurniawati and Sardjono, 2014).

Fusarium solani has been reported as a rot pathogen by many authors. Fusarium species including $F$. solani are the most predominant soil-borne fungal pathogens on plants causing severe economic damages especially in wheat, potato, pea, bean, rice and corn in Iran (Saremiet al., 2011). Fusarium solanif. sp. cu curbitae has been reported to cause crown and root rot on $\mathrm{Cu}$ curbitapepo (zucchini squash) in Spain, and experiments conducted to determine the ability of the pathogen to survive in bags filled with food products showed that the pathogen survived for 20 months (Perez-Hernandez et al., 2017). F. solani has been reported to be associated with crown disease of oil palm (Hafiziet al., 2014) and as the causal agent of crown and root rot of strawberry crops in Southwestern Spain (Pastrana et al., 2014).

\section{Conclusion}

In this study, eight fungal organisms associated with Jatropha curcas were isolated using traditional cultural techniques and identified using molecular methods. The use of traditional cultural techniques in the identification of microorganisms is not reliable as misinterpretation and misidentification of organisms abounds. The cultural techniques used in this study only aided in the processes that led to the correct identification of the isolates. The morphological characteristics were only able to suggest the suspected organisms but cannot be used to successfully characterize the isolates to the species level. Identification of the fungal isolates by the use of molecular techniques such as Polymerase Chain Reaction amplification and sequencing of the ITS regions of the fungal genome yielded a good result. Some of the organisms isolated in this study exist as endophytes, having a symbiotic relationship with plants. Under stress or unfavourable conditions, endophytic organisms become pathogenic causing deterioration on plants. These fungi 
cause deterioration of the seeds, leaves and bark (or stem) of Jatropha curcas plants leading to a decrease in the quantity and quality of the plant products obtained. This study has provided information on some of the fungal organisms associated with Jatropha curcas which will help in proffering prevention and control measures to reduce the incidence of some of these pathogenic organisms on $\mathrm{J}$. curcas.

\section{Refrences}

Agbogidi, O. M., Akparobi, S. O. and Eruotor, P. G. (2013). Health and Environmental Benefits of Jatrophacurcas (Linn.). Appl. Sci. Rep., 1(2): 36-39.

Castro-Escarpulli, G., Alonso-Aguilar, N. M., Rivera, G., Bocanegra-Garcia, V., Guo, X., Jurez-Enrquez, S. R., Luna-Herrera, J., Martnez, C. M., Guadalupe, A. M. (2016). Identification and Typing Methods for the Study of Bacterial Infections: A Brief Review and Mycobacterial as Case of Study. Arch. Clin. Microbiol., 7: 1-10.

Costa, A. M., Ribeiro, W. X., Kato, E., Monteiro, A. G.and Peralta, R. M. (2008). Production of Tannase by Aspergillus tamari in Submerged Cultures. Braz. Arch. Biol. Technol., 51(2): 399-404.

Da Silva-Junior, E. A., Paludo, C. R., Valadares, L., Lopes, L. P., Do Nascimento, F. S. and Pupo, M. T. (2017). Aflatoxins produced by Aspergillusnomius ASR3, a Pathogen Isolated from the Leaf-cutter Ant Atta sexdensrubropilosa. Braz. J. Pharmacog., 27: 529-532.

Franco-Duarte, R., Cernáková, L., Kadam, S., Kaushik, K. S., Salehi, B., Bevilacqua, A., Corbo, M. R., Antolak, H., Dybka-St epie, K., Leszczewicz, M., Tintino, S. R., Alexandrino de Souza, V. C., Sharifi-Rad, J., Coutinho, H. D., Martins, N. and Rodrigues, C. F. Advances in Chemical and Biological Methods to Identify Microorganisms-From Past to Present. Microorg., 7: 130-161.

Hafizi, R., Salleh, B. and Latiffah, Z (2014). Morphological and Molecular Characterization of Fusarium solani and $F$. oxysporum
Associated with Crown Disease of Oil Palm. Braz. J. Microbiol., 4(3): 959-968.

Islam, A., Yaakob, Z. and Anuar, N. (2011). Jatropha: A Multipurpose Plant with Considerable Potential for the Tropics. Sci. Res. Essays, 6(13): 2597-2605.

ISTA (International Seed Testing Association) (2016). International Rules for Seed Testing. Rules Ammendments. Seed Sci. Technol., 29: 1-127.

Jayaraman, P., NesaPriya, S., Parameshwari, S., ShyamalaPriya, S., Jawahar, N. andSekarBabu, H. (2011). Occurrence of Storage Fungi in Jatropha (Jatrophacurcas L.) Seeds. African J. Microbiol. Res., 5(5): 475480.

Jin-Hyeuk, K., Jae-San, R., Tran, T. and Okhee, C. (2012). Soft Rot of Rhizopusoryzae as a Postharvest Pathogen of Banana Fruit in Korea. Mycobiol., 40(3):214-216.

Jin-Hyeuk, K., Jinwoo, K., and Won-Il, K. (2011). First Report of Rhizopusoryzae as a Postharvest Pathogen of Apple in Korea. Mycobiol., 39(2): 140-142.

Kumar, S., Stecher, G., Li, M., Knyaz, C. and Tamura K. (2018). MEGA X: Molecular Evolutionary Genetics Analysis across Computing platforms. Mol. Biol. Evol. 35:1547-1549.

Kurniawati, T. and Sardjono, R. I. (2014). Isolation of Rhizopusoryzaefrom Rotten Fruit and its Potency for Lactic Acid Production in Glucose Medium with and without Addition of Calcium Carbonate. Agritech, 34(2): 170-176.

Lateef, A., Garuba, T., Sa'ad, G., Olesin, M., Eperetun, G. and Tiamiyu, B. (2019). Isolation and Molecular Identification of Fungal Endophytes from Green Leaves of Physic Nut (Jatropha curcas) from Unilorin Plantation, Ilorin, Nigeria. Sri Lankan J. Biol., 4 (1): 1-13.

Louw, J. P. and Korsten, L. (2014). Pathogenic Penicillium spp. on Apple and Pear. Plant Dis., 98:590-598. 
Maghuly, F., Jankowicz-Cieslak, J., Till, B. and Laimer, M. (2013). The Use of Ecotilling for the Genetic Improvement of Jatrophacurcas. In: Jatropha, Challenges for a New Energy Crop. Volume 2: Genetic Improvement and Biotechnology. Bahadur, L., Sujatha, M., Carels, N. (eds). Springer New York Heidelberg Dordrecht London, pp. 335-349.

Marcenaro, D. and Valkonen, J. (2016) Seedborne Pathogenic Fungi in Common Bean (Phaseolus vulgaris cv. INTARojo) in Nicaragua. PLOSONE, 11(12): 1-18.

Muhammad, W., Abdul, K., Muhammad, H., Raheem, S., Sang-Mo, K., Jong-Guk, K., InJung, L. (2015). Endophytic Fungi Promote Plant Growth and Mitigate the Adverse Effects of Stem Rot: An example of Penicilliumcitrinum and Aspergillus terreus. J. Plant Inter., 10(1): 1-18.

Nwaukwu, I. A., Akinseye, O. F. and Ataga, A. E. (2014). Mycoflora of Physic Nut (Jatrophacurcas): A Biofuel Plant. Nig. J. Bot., 27(2): $191-198$.

Ogbole, O. O, Adebayo-Tayo, B. C., Salawu, K. M. and Okoli, V. C (2017). Molecular Identification and Antimicrobial Activity of Endophytic Fungi Aspergillustamarii (Trichomaceae). Nig. J. Pharm. Sci., 16: 4148.

Pastrana, A. M., Capote, N., De los Santos, B., Romero, F. and Basallote-Ureba, M. J. (2014). First Report of Fusarium solanicausing Crown and Root Rot on Strawberry Crops in Southwestern Spain. Plant Dis., 98(1): 161.

Perez-Hernandez, A. Porcel-Rodriguez, E. and Gomez-Vazquez, J. (2017). Survival of Fusarium solani f. sp. curcurbitae and Fungicide Application, Soil Solarization, and Biosolarization for Control of Crown and Foot Rot of Zucchini Squash. Plant Dis., 101(8): 1507-1514.

Rahman, M. M., Ahmad, S. H., Mohamed, M. T. and Abrahman, M. Z. (2014). Antimicrobial Compounds from Leaf Extracts of Jatrophacurcas, Psidiumguajava and
Andropraphispaniculata. Sci. World J., 9(2): 19.

Salvador-Fegueroa, M., Magana-Ramos, J., Vazquez-Ovando, J., Adriano-Anaya, M. andOvando-Medina, I. (2015). Genetic Diversity and Structure of Jatrophacurcas (L.) in its Centre of Origin. Plant Gen. Res., 13(1): $9-17$.

Santos, G. R., TozzeJúnior, H. J., Corrêa de Sa, D. A, Furtado, G. Q. and Massola-Júnior, N. S. (2013). Etiology and Pathogenicity of two Different Isolates of Colletotrichumspp. obtained from Physic Nut Seeds. J. Seed Sci., 35(2):139-146.

Saremi, H., Okhovvat, S. M. and Ashrafi, S. J. (2011).Fusarium Diseases as the main Soilborne Fungal Pathogen on Plants and their Control Management with Soil Solarization in Iran. African J. Biotech., 10(80): 1839118398.

Tam, E. W.,Chen, H. K. Lau, E. C., Ngan, A. H., Fung, K. S., Lee, K., Lam, C., Yuen, K., Lau, S. K. and Woo, P. C. (2014). Misidentification of Aspergillus nomiusand Aspergillus tamarii as Aspergillus flavus. Characterization by Internal Transcribed Spacer, $\beta$-Tubulin, and Calmodulin Gene Sequencing, Metabolic Fingerprinting, and Matrix-Assisted Laser Desorption Ionization-Time of Flight Mass Spectrometry. J. Clin. Microbiol., 52(4): 11531160.

Wang, F., Zhao, L. and Li, G. (2011). Identification and Characterization of Botryosphaeria spp. causing Gummosis of Peach Trees in Hubei Province, Central China. Plant Dis., 95(11): 1378-1384.

Worang, R. L., Dharmaputra, O. S. and Syarief, R. M. (2008). The Quality of Physic nut (JatrophacurcasL.) Seeds Packed in Plastic Material During Storage. Biotropia, 15(1): 2536. 